UDC 621.039

V. Skalozubov, DSc, Prof.,

M. Alali,

N. Bilous,

T. Gablaya,

V. Kochneva,

D. Pirkovsky,

O. Chulkin, $\mathrm{PhD}$

Odessa National Polytechnic University, 1 Shevchenko Ave., Odessa, Ukraine, 65044; e-mail: gntcod@te.net.ua

\title{
WATER HAMMERS INTO PIPELINE SYSTEMS BECAUSE OF OSCILLATORY INSTABILITY
}

\begin{abstract}
В.І. Скалозубов, М. Алалі, М.В. Білоус, Т.В. Габлая, В.Ю. Кочнева, Д.С. Пірковський, О.О. Чулкин. Гідродинамічні удари у трубопровідних системах внаслідок коливальної нестійкості. У статті представлений аналіз відомих досліджень в області визначення причин та умов виникнення гідроударів в трубопровідних системах різних енергоустановок. Виникнення гідродинамічних ударів супроводжується імпульсним високоамплітудним динамічним впливом на енергетичне обладнання $\mathrm{i}$ елементи трубопровідних систем. При гідродинамічних ударах відбувається перехід кінетичної енергії гальмування потоку в енергію імпульсу тиску гідродинамічного удару. Гідродинамічні удари можуть істотно впливати на надійність і працездатність енергетичного обладнання і елементів трубопровідних систем. Встановлено, що найменш вивченими причинами та умовами виникнення гідроударів в трубопровідних системах енергоустановок є ефекти коливальної гідродинамічної нестійкості. Розглянуто метод визначення умов виникнення гідроударів в замкнутих контурах примусової циркуляції енергетичних систем. Метод заснований на умовах виникнення коливальної гідродинамічної нестійкості внаслідок інерційності напірно-витратної характеристики насосів. Інерційність визначається «запізненням» у часі реакції напірно-витратної характеристики насосу на зміну гідродинамічних параметрів потоку. Представлена верифікація розглянутого методу визначення умов виникнення гідродинамічних ударів на прикладі відомих результатів експериментальних досліджень. Для верифікації розглянутого методу використані експериментальні дані професора О.В. Королева, отримані на замкнутому циркуляційному експериментальному стенді 3 поршневими насосами. Узгодження розрахунків і експериментів цілком задовільне. Зі узгодження розрахункових обгрунтувань $\mathrm{i}$ експериментальних даних виняток становить тільки один режим, який також не корелює з іншими експериментальними даними.

Ключові слова: Гідродинамічні удари, верифікація, енергетичне обладнання, трубопровідні системи, інерційність, коливальна гідродинамічна нестійкість, напірно-витратна характеристика насосів

V. Skalozubov, M. Alali, N. Bilous, T. Gablaya, V. Kochneva, D. Pirkovsky, O. Chulkin. Water hammers into pipeline systems because of oscillatory instability. The paper presents an analysis of well-known research on determining of the causes and conditions for water hammers into pipeline systems of different power facilities. Pulse high-amplitude dynamic impact on power equipment and pipeline system elements accompanies water hammers. When water hammers, the kinetic energy of the flow stagnation turns into the energy of the water hammer pulse. Water hammers can significantly affect reliability and operability of power equipment and pipeline system elements. It was revealed that oscillatory hydrodynamic instability effects are the least studied causes and conditions for water hammers into pipeline systems of power facilities. The method to determine the conditions for water hammers in closed forced circulation circuits of energy systems is considered. The method is based on the conditions for oscillatory hydrodynamic instability because of the inertia of the pump head-flow characteristic. The "time delay" of response of the pump head-flow characteristic to changing the flow hydrodynamic parameters defines the inertia. Verification of the considered method to specify conditions for water hammers is provided by the example of known results of experimental research. Professor Korolev's experimental data obtained at the closed circulating experimental stand with piston pumps are used to verify the considered method. Calculations and experiments agree quite satisfactorily with the exception of a single mode, which also does not correlate, with other experimental data.

Keywords: water hammer, verification, power equipment, pipeline system, inertia, oscillatory hydrodynamic instability, pump headflow characteristic
\end{abstract}

Introduction. This work is devoted to the development of an original verified method for determining the conditions for the occurrence of water hammer due to the inertia of pump head flow characteristic, leading to oscillatory hydrodynamic instability in closed pipeline systems of power equipment.

Analysis of literature data and problem statement. In the pipeline systems of various power plants, water hummers (WH) were recorded, accompanied by a pulse high-amplitude increase in pressure on local hydraulic resistances $[1-8]$. The occurrence of WH significantly affects the reliability and service life of power equipment.

DOI: 10.15276/opu.1.57.2019.10

(C) 2019 The Authors. This is an open access article under the CC BY license (http://creativecommons.org/licenses/by/4.0/). 
Much research has been devoted to the study of the causes and effects of WH in pipeline systems.

For single-phase flows / environments, the main causes of WH may be:

- accelerated valve closure, accompanied by abrupt deceleration of the flow [9 - 13];

- transient modes with significant inertia; pressure-flow characteristics of pumps (PFC) [14 - 16];

- resonance effects when the frequency of the medium's pumping coincides with the natural frequency of the pipeline system [17];

- the occurrence of oscillatory hydrodynamic instability, accompanied by high amplitude fluctuations in pressure and flow velocity [18-20].

A review of these studies is presented, for example, in the monograph [21]. In these works, water hummers were mainly investigated because of a sharp decrease in the flow area of pipeline systems. The issues of hydrodynamic impacts due to oscillatory instabilities in single-phase flows are studied very insufficiently.

The least studied causes and conditions for the occurrence of WH in pipeline systems are the effects of hydrodynamic instability. A significant contribution to the study of various types of thermohydrodynamic instability was made by the scientific school of Professor V.A. Gerliga ([11, 12] and others). The following types of thermohydrodynamic instability can be classified:

- aperiodic instability accompanied by a "jump-like" change of parameters;

- high-frequency oscillatory instability in condensable streams;

- low-frequency oscillatory instability in two-phase flows of heated channels.

However, the problems of oscillatory instability in single-phase flows due to the inertia of PFC pumps have not been studied sufficiently. The proposed work is devoted to the development of an original verified method for determining the conditions for the occurrence of water hammer due to the inertia of PFC, leading to oscillatory hydrodynamic instability in closed pipeline systems of power equipment. This situation determines the relevance and objectives of the proposed work.

The main goal of the work is to develop and verify a method for determining the conditions for the occurrence of a WH due to vibrational hydrodynamic instability in closed pipeline systems with pumping equipment.

The main provisions of the method for determining the conditions for the occurrence of a WH due to oscillatory instability. The physical model of the conditions for the occurrence of WH is based on the effect of the inertia of the PFC pressure pump pressure $\left(\Delta P_{p}\right)$, depending on the back pressure $P$ and the average flow rate $v$ :

$$
I=\frac{d \Delta P_{p}(P, v)}{d t},
$$

where $t$ is the process time.

Let, for example, at the initial time $t=0$, an impulse of increasing backpressure $\delta P$ appears at the pump output, which initiates the impulse of decreasing the flow velocity $\delta v$. Increasing the back pressure and reducing the flow rate initiates an increase in the pump head $\delta \Delta P_{p}$.

The increase in pump head initiates with a "lag" caused by the inertia of PFC, after a certain period of time $\Delta t$ an increase in flow rate and a corresponding decrease in backpressure.

An increase in the flow rate and a decrease in back pressure initiates a decrease in the head $\delta \Delta P_{p}$. However, due to the same inertia of the PFC pump, the reduction in pressure does not occur instantaneously, but with a "delay" for a certain period of time $\Delta t$. Thus, due to the inertia of the PFC pump response to changes in hydrodynamic parameters, an oscillatory process develops in the system (Fig. 1).

In a format of relatively small (with respect to steady-state values) pressure fluctuations and flow rates, the hydrodynamic equations have the following form:

$$
-\rho \frac{d V_{g}}{d P} \frac{d \delta P}{d t}=\rho F\left(\delta v-\delta v_{D}\right),
$$




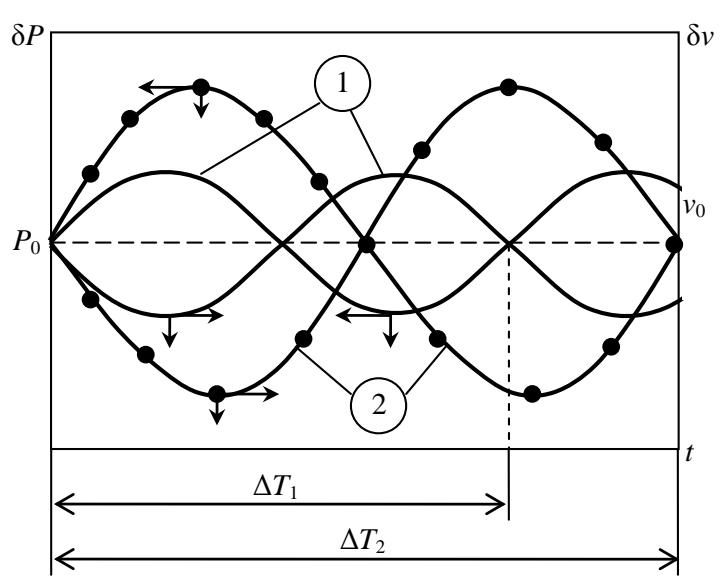

Fig. 1. The generalized model of the development of oscillatory hydrodynamic instability, determined by the inertia of PFC pump I: $1-I_{1} ; 2-I_{2}<I_{1}$

$$
\begin{gathered}
\frac{d \delta v}{d t}=\frac{1}{\rho L_{1}} \delta \Delta P_{p}-\frac{\xi_{1}}{L_{1}} v_{0} \delta v, \\
\delta \Delta P_{p}=\int_{0}^{t} \delta I(P, v, \Delta t) d \tau, \\
\frac{d \delta v_{D}}{d t}=\frac{\xi_{2}}{L_{2}} v_{0} \delta v_{D},
\end{gathered}
$$

where $\rho$ is the flux density;

$V_{g}$-the volume of gas in the damping device (DD);

$F$ is the flow area of the pipeline;

$\xi_{1}, \xi_{2}$ is the total coefficient of hydraulic resistance in the area $L_{1}$ and $L_{2}$, respectively;

$v_{D}$ - flow rate at the outlet of the damping device (DD).

$$
\delta I(\Delta t)=\left\{\begin{array}{l}
0 \text { at } \tau \leq \Delta t, \\
\frac{\partial I}{\partial v} \delta v+\frac{\partial I}{\partial P} \delta P \text { at } \tau>\Delta t .
\end{array}\right.
$$

For high frequency oscillation harmonics:

$$
\Delta t \approx L / a_{s},
$$

where $a_{s}$ - the speed of sound in the environment.

For low frequency oscillation harmonics:

$$
\Delta t \approx L / v \text {. }
$$

In the general case, the system of equations (2) - (8) can be solved by numerical methods. The calculations took into account only low-frequency harmonics of oscillations of hydrodynamic parameters with the highest energy and amplitude.

For a concrete example, the results obtained on the experimental bench of A.V. Queen [17, 18] - Fig. 2.

The experimental stand was a closed circulation loop with a single-linear piston pump 2HCГ$0.063 / 20$ or a three-linear piston pump $2 \mathrm{HCГ}-0.42 / 15$. During the test, pressure fluctuations were recorded with low-inertia sensors at three points of the discharge line: at the pump outlet; before DD; after DD.

The experiments were carried out for three levels of working pressure $P_{0} 5.0 ; 10.0$ and $15.0 \mathrm{MPa}$ and pump frequencies of 1000 and 1500 rpm. Two modes of operation of pumps on liquefied gas were experimentally investigated: conditions for normal operation; artificial "disruption" of the pump operation by a spinning device from the seat of the suction valve. The verification results are presented in Fig. 3.

Taking into account the uncertainties of individual source data, the results of computational modeling are in satisfactory agreement with experimental data on pressure fluctuations in the operating modes of piston pumps. An exception is the operating mode and the mode of breakdown at a pressure of 5.0 $\mathrm{MPa}$ and the frequency of the pump motors of 1500 revolutions/min. However, these experimental data do not agree with the other experimental results.

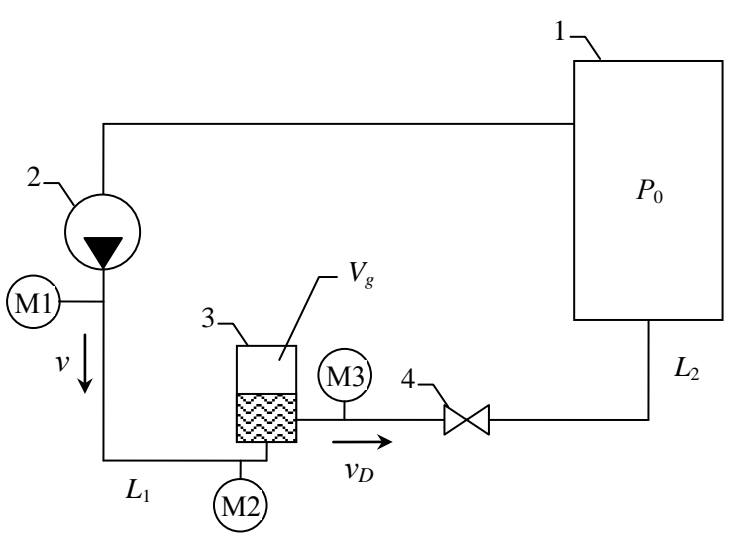

Fig. 2. Computational model of the experimental stand $[17,18]$ :

1 - hydro capacitance; 2 - pump;

3 - damping device (DD); 4 - fittings;

M1, M2, M3 - sensors for measuring pressure pulsations 


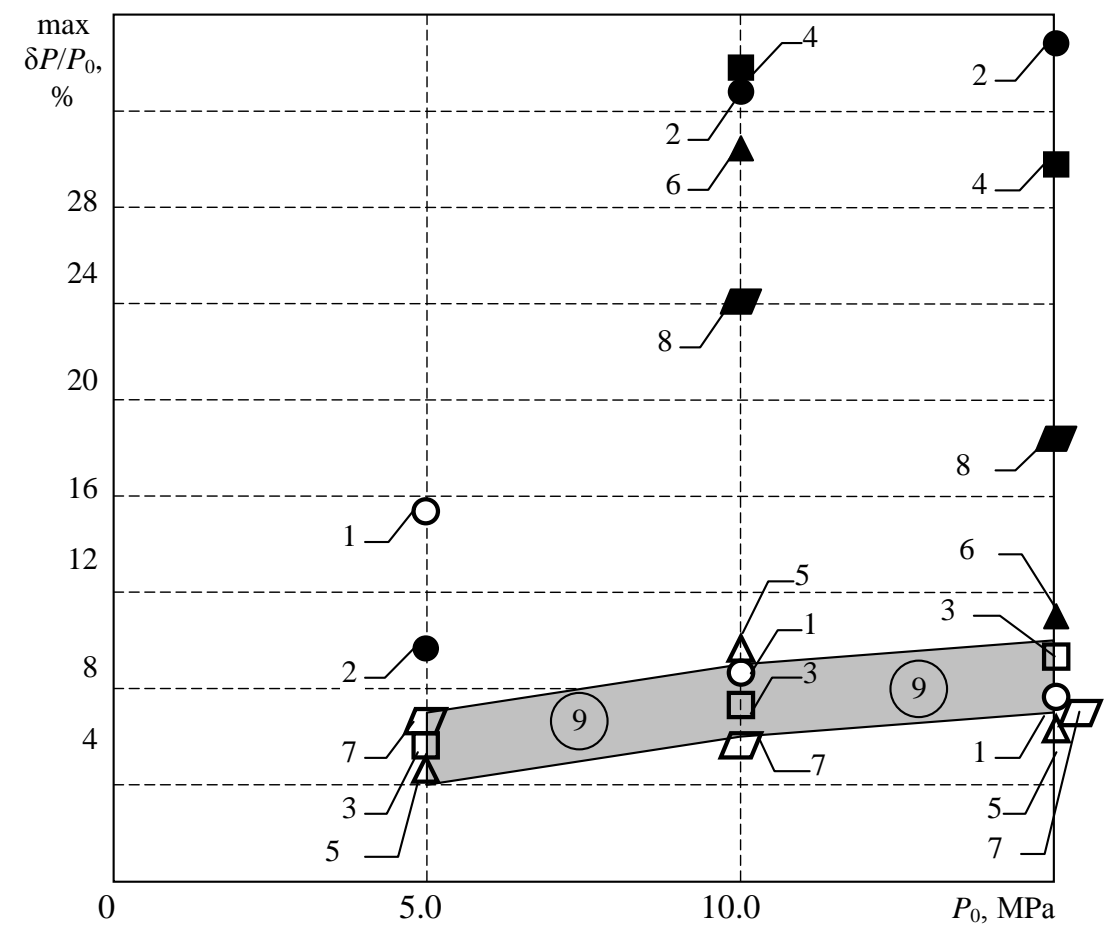

Fig. 3. Verification of computational methods with experimental data [17, 18]:

1 - norm, $1500 \mathrm{rpm}$, staff DD; 2 - stall, $1500 \mathrm{rpm}$, staffing DD; 3 - norm, $1000 \mathrm{rpm}$, full-time remote control; 4 - stall, 1000 rpm, staffing DD; 5 - norm, 1500 rpm, modernized DD; 6 - stall, 1500 rpm, upgraded DD; 7 - norm, 1000 rpm, modernized DD; 8 - stall, 1000 rpm, modernized DD; 9 - area of account

Research results. The main result of the work is an original verified method for determining the conditions for the occurrence of water hammer due to the inertia of PFC, leading to oscillatory hydrodynamic instability in closed pipeline systems of power equipment.

Conclusion. The method of determining the conditions for the occurrence of water hammer in the closed circuits of the forced circulation of energy systems is considered. The method is based on the conditions of occurrence of oscillatory hydrodynamic instability due to the inertia of the pressureflow characteristics of the pumps. The inertia is determined by the "delay" in the reaction time of the pressure-flow characteristics of the pump to a change in the hydrodynamic parameters of the flow.

The verification of the considered method for determining the conditions for the occurrence of water hammer using the example of the known results of experimental studies is presented. Coordination of calculations and experiments is quite satisfactory.

\section{Література}

1. Комплекс методов переоценки безопасности атомной энергетики Украины с учетом уроков экологических катастроф в Чернобыле и Фукусиме / Скалозубов В.И., Мазуренко А.С., Козлов И.Л., Оборский Г.А. и др. Одесса: Астропринт, 2013. 244 с.

2. Safwat Hemmat H., Arustu Asif H., Husaini Syed M. Systematic Methodology for Diagnosis of Water Hammer in LWR power plants. Nucl. Eng. and Design. 1990. 122. P. 365-376.

3. NUREG/CR-6519. Screening Reactor Steam/Water Piping Systems for Water Hammer. 1997.

4. Bjorge R.W., Griffith P. Initiation of Water Hammer in Horizontal and Nearly Horizontal Pipes Containing Steam and Subcooled Water. ASME Journal of Heat Transfer. 1984. 106(4). P. 835-840.

5. Lee S.C., Bankoff S.G. Stability of Steam-Water Countercurrent Flow in an Inclined Channel: Part II Condensation-Induced Water Hammer. ASME Journal of Heat Transfer. 1984. 106(4). P. 900-902. 
6. Prasser H.-M., Bottger A., Zschau J., Baranyai G., Ezsol Gy. Thermal effects during condensation induced water hammer behind fast acting valves in pipelines. $11^{\text {th }}$ Intern. Conf. on Nuclear Engineering (Tokyo, JAPAN, 20-23 April 2003), ICONE11-36310. Tokyo, 2003. Van Duyne D.A., Yow W., Sabin J.W. Water Hammer Prevention, Mitigation and Accommodation. Volume 1: Plant Water Hammer Experience. EPRI Report NP-6766. 1992.

7. Van Duyne D.A., Yow W., Sabin J.W. Water Hammer Prevention, Mitigation and Accommodation. Volume 1: Plant Water Hammer Experience. EPRI Report NP-6766. 1992. P. 166-174.

8. Block J. A. Condensation-driven fluid motions. Int. Journal on Multiphase Flow. 1980. Vol. 6. P. 113-129.

9. Делайе Дж., Гио М., Ритмюллер М. Теплообмен и гидродинамика двухфазных потоков в атомной и тепловой энергетике. Москва : Энергоатомиздат, 1984. 422 с.

10. Condensation driven water hammer studies for feed water distribution pipe / Savolainen S., Katajala S., Elsing B. et al. Fourth Intern. Seminar on Horizontal Steam Generators (Lappeenranta, Finland, 11-13 March 1997). Lappeenranta, 1997.

11. Герлига В.А., Хабенский В.Б. Нестабильность потока теплоносителя в энергооборудовании. Москва: Энергоиздат, 1994. 288 с.

12. Коврижкин Ю.Л., Скалозубов В. И. Термоакустическая неустойчивость теплоносителя в активной зоне водоводяных энергетических реакторов. Одесса: ТЭС, 2003. $171 \mathrm{c}$.

13. Фокс Д.А. Гидравлический анализ неустановившегося течения в трубопроводах. Москва: Энергоиздат, 1981. $247 \mathrm{c.}$

14. Филин Н.В. Жидкостные криогенные системы. Ленинград: Машиностроение, 1985. 247 с.

15. Королев А.В. Анализ и моделирование теплоэнергетического оборудования, работающего с двухфазными течениями. Одесса: Астропринт, 2010. 456 с.

16. Жуковский Н.Е. О гидродинамическом ударе в водопроводных системах. М.-Л.: ГИТТЛ, 1949. 100 с.

17. Korolyov O.V., Zhou HuiYu. Dynamic damper pressure fluctuation in the pumping systems. Праųi Одеського політехнічного університету. 2016. Issue 1(48). P. 35-41.

18. Королев А.В., Чжоу Х. Ю. Исследование динамики поршневого насоса в нормальном режиме и при срыве подачи. Холодильная техника. 2016. Вып. 5, № 52. С. 4-8.

19. Безруков Ю.А., Лисенков Е.А., Селезнев А.В. Анализ возможности гидроударов в первом контуре реакторов ВВЭР. Обеспечение безопасности АЭС с ВВЭР: материалы 6-й междунар. науч.техн. конф. (Подольск, Россия, 26-29 мая 2009 г.). Подольск : ОКБ «Гидропресс», 2009.

20. Determining the Conditions for the Hydraulic Impacts Emergence at Hydraulic Systems / Mazurenko A.S., Skalozubov V.I., Chulkin O.A. et al. Problems of the Regional Energetics. Kishinau, 2017. No. 2(34).

21. Скалозубов В. И., Чулкин О.А., Пирковский Д.С. Гидроудары вследствие теплогидродинамической неустойчивости. LAP LAMBERT Academic Publishing. 2018. 64 c.

\section{References}

1. Skalozubov V.I., Mazurenko A.S., Kozlov I.L., \& Oborsky G.A. et al. (2013). A set of methods to review the safety of nuclear power engineering in Ukraine, taking into account the lessons of Chernobyl and Fukushima ecological catastrophes. Odessa: Astroprint.

2. Safwat, Hemmat H., Arustu, Asif H., Husaini, Syed M. (1990). Systematic methodology for diagnosis of water hammer in LWR power plants. Nucl. Eng. and Design, 122, 365-376.

3. NUREG/CR-6519. Screening Reactor Steam/Water Piping Systems for Water Hammer (1997).

4. Bjorge, R. W., \& Griffith, P. (1984). Initiation of Water Hammer in Horizontal and Nearly Horizontal Pipes Containing Steam and Subcooled Water. ASME Journal of Heat Transfer, 106(4), 835-840.

5. Lee, S.C., \& Bankoff, S.G. (1984). Stability of Steam-Water Countercurrent Flow in an Inclined Channel: Part II Condensation-Induced Water Hammer. ASME Journal of Heat Transfer, 106(4), 900-902.

6. Prasser, H.-M., Bottger, A., Zschau, J., Baranyai, G., \& Ezsol, Gy. (2003). Thermal effects during condensation induced water hammer behind fast acting valves in pipelines, 11th Intern. Conf. on Nuclear Engineering, ICONE11-36310, Tokyo, JAPAN, (20-23 April 2003).

7. Van Duyne, D.A., Yow, W., \& Sabin, J.W. (1992). Water Hammer Prevention, Mitigation and Accommodation. Volume 1: Plant Water Hammer Experience, EPRI Report NP-6766.

8. Block, J.A. (1980). Condensation-Driven Fluid Motions. Int. Journal on Multiphase Flow, 6, 113-129.

9. Delhaye, J.M., Giot, M., \& Rietmuller, M.L. (1984). Thermohydraulics of Two-Phase Systems for Industrial Design and Nuclear Engineering. Moscow: Energoatomizdat. 
10. Savolainen, S., Katajala, S., \& Elsing, B. et al. (1997). Condensation Driven Water Hammer Studies for Feed Water Distribution Pipe”, Fourth Intern. Seminar on Horizontal Steam Generators (Lappeenranta, Finland, 11-13 March 1997). Lappeenranta.

11. Gerliga, V.A., \& Khabenskiy, V.B. (1994). Instability of the Coolant Flow in Power Equipment. Moscow: Energoizdat.

12. Kovrizhkin, Yu.L., \& Skalozubov, V.I. (2003). Thermoacoustic Instability of the Coolant in the WWER Core. Odessa: TES.

13. Foks, D.A. (1981). Hydraulic Analysis of Unsteady Flow in Pipelines. Moscow: Energoizdat.

14. Filin, N.V. (1985). Liquid cryogenic systems. Leningrad: Mashinostroenie.

15. Korolev, A.V. (2010). Analysis and Modelling of Heat Power Equipment Operating Two-Phase Flows. Odessa: Astroprint.

16. Zhukovskiy, N. E. (1949). About Hydrodynamic Impact in Water Supply Systems. M.-L.: GITTL.

17. Korolyov O.V., Zhou HuiYu (2016). Dynamic Damper Pressure Fluctuation in the Pumping Systems. Proceedings of Odessa Polytechnic University, 1(48), 35-41.

18. Korolev, A.V., \& Zhou Hui Yu (2016). Research of Dynamics at Normal Operation and Interrupted Feed of Piston Pumps. Refrigeration Engineering and Technology, 52, 52, 4-8.

19. Bezrukov, Yu.A., Lisenkov, E.A., \& Seleznev, A.V. (2009). Analysis Of Primary-Side Water Hammer For WWER-Type Reactors. Proceedings of the 6th Scientific and Technical Conferences:Safety Assurance of NPP with VVER, (May 26-29, 2009). Podolsk: OKB Gidropress.

20. Mazurenko, A.S., Skalozubov, V.I., \& Chulkin, O.A. et al. (2017). Determining the Conditions for the Hydraulic Impacts Emergence at Hydraulic Systems. Problems of the Regional Energetics, 2(34).

21. Skalozubov V.I., Chulkin O.A., \& Pirkovsky D.S. (2018). Water hammer due to heat-hydrodynamic instability. LAP LAMBERT Academic Publishing.

Скалозубов Володимир Іванович; Skalozubov Volodymyr, ORCID: https://orcid.org/0000-0003-2361-223X

Алалі Мохаммад; Alali Mohammad, ORCID: https://orcid.org/0000-0003-4052-9331

Білоус Микола Вікторович; Bilous Nikolay, ORCID: https://orcid.org/0000-0001-8492-4152

Габлая Таїсія Володимирівна; Gablaya Taisiya, ORCID: https://orcid.org/ 0000-0003-3184-5674

Кочнева Валерія Юріївна; Kochneva Valeriya, ORCID: https://orcid.org/ 0000-0003-3184-5674

Пірковський Денис Сергійович; Pirkovskiy Denis, ORCID: https://orcid.org/0000-0002-6638-9499

Чулкін Олег Олександрович; Chulkin Oleg, ORCID: https://orcid.org/0000-0001-5048-4545 